\title{
FUNCTIONAL FOODS: THE NEW CONCEPT EMERGING FROM THE TRADITIONAL NUTRITION
}

\author{
Milka Nashar, Diana Ivanova \\ Faculty of Pharmacy, Department of Biochemistry, Molecular Medicine and \\ Nutrigenomics, Medical University of Varna, Bulgaria
}

\begin{abstract}
The present study was aimed to review the scientific evidences that the traditional nutrition of Bulgarians during the centuries could be considered as a dietary pattern with functional characteristics. Historical sources indicated that the diet of our ancestors was low processed, rich in dietary fibers, polyphenols and many other functional components. Traditional foods and beverages containing probiotics were identified as traditional functional foods. Based on the concept of functional foods we concluded that the traditional diet of Bulgarians could be considered as a healthy nutritional pattern.
\end{abstract}

Keywords: functional foods, traditional nutrition, healthy diet

\section{INTRODUCTION}

It is not a new knowledge that the dietary pattern may modulate target functions in the body and thus may have various beneficial physiological effects. Along with the healthy lifestyle, the diet could contribute for maintaining optimal health and for reducing the risk of certain diseases (50). Modern nutritional science aims at identifying biologically active components in foods and revealing the mechanisms behind their benefits. In the last 15 years the accumulation of scientific data led to formation of a new concept in nutritional science: the concept of functional foods (65)

It is believed that changing in nutritional habits after the World War II is one of the factors contrib-

Address for correspondence:

Milka Nashar

Medical University of Varna

55 Marin Drinov Str.

9002 Varna, Bulgaria

e-mail:milka.nashar@mu-varna.bg

Received: May 21, 2015

Accepted: June 16, 2015 uted to increased morbidity, especially with regard to cardiovascular diseases, diabetes and cancer (34). Bulgaria, like most European countries, was also affected by these changes due to adopted "western diet" pattern. A cross-country survey among young people in four European countries reported that a high percent of Bulgarian students very frequently consume fast foods and products containing refined sugar (9). Moreover, according to an observation and analysis focusing European countries, approximately one third of adult Bulgarians are obese and more than $20 \%$ of children in pre-puberty age are overweight or obese $(93,155)$. A survey aiming to assess differences in functional foods consumption between European countries revealed that consumers in only few European countries are familiar with functional foods as a part of their everyday diet. It is not a surprise that most of these countries are Mediterranean and Scandinavian. (107). Both Mediterranean and Nordic diets are considered as healthy dietary patterns that are low or maybe not affected by the western lifestyle $(20,126,134)$. Thanks to the advances of nutritional science technologies, particularly of molecular biology and nutrigenomics, it is known that the genetic pool of population plays a crucial role in the met- 
Functional foods: the new concept emerging from the traditional nutrition

abolic response to environmental factors, including the diet (34). In this respect, functional foods are vital to health. The question arises, which of the traditional foods in the diet of the Bulgarians could be regarded as functional.

\section{FUNCTIONAL FOODS CONCEPT AND DEFINITION}

There is no universally accepted definition for functional foods. A large number of conceptual definitions could be found in the scientific literature and on the web sites of many organizations, in the nutrition sciences field (40). Most of these definitions are based on several common key concepts: a) health benefits: a food could be classified as functional if it is known to enhance target functions or to reduce the risk of specific diseases; b) level of function: to provide benefits beyond the basic nutritional functions; c) nature of food: a functional food should be or should look like a traditional food; d) dietary pattern: a functional food should be a part of the normal diet. In this context, the most complete working definition of functional foods was proposed by the EC Concerted Action on Functional Food Science in Europe (FUFOSE): “.... a food that beneficially affects one or more target functions in the body beyond adequate nutritional effects in a way that is relevant to either an improved state of health and well-being and/ or reduction of risk of disease. It is consumed as part of a normal food pattern. It is not a pill, a capsule or any form of dietary supplement." (44).

\section{SCIENTIFIC BASIS OF FUNCTION- AL FOODS CONCEPT}

In 1980s the government in Japan introduced a regulatory system for certain foods with documented health benefits, with the intent to improve the health of the aging population $(10,133)$. This could be considered as the birth date of the functional foods concept, adopted and developed later by the United States and by other economically developed countries (132). This governmental attitude provoked the scientific interest to investigate the relationship between foods beneficial characteristics and related target functions $(40,44)$. Any claim for health benefits attributed to functional foods should be based on strong scientific proofs. The effect of the active compounds on target functions as well as the interactions with other dietary components and possible adverse interactions with pharmaceutical agents should be clarified (90).

Thanks to the rapid development of nutritional science in recent years, accumulated scientific data about health benefits of the functional foods became a fundamental knowledge.

Table 1 summarizes the major groups of functional components/foods and scientific data supporting their specific health benefits:

\section{RECOGNITION OF FUNCTION- AL FOODS IN BULGARIAN TRADI- TIONAL DIET}

Sufficient scientific data exist supporting the theory about functional characteristics and health benefits of some traditional dietary patterns, such as Mediterranean, Nordic and Maori diet $(14,23,24,78,106,159)$. Based on the historical sources and in accordance with existing scientific data this study was aimed to examine which foods in the traditional diet of our ancestors could be considered as functional.

The Bulgarian nation was formed from the merging of three major ethnic groups: Thracian, Slavic and Bulgar tribes. Their nutritional habits along with the impact of other ethnic groups and nations, such as Cumans, Illyrians and mainly Ottomans were the basis in formation of Bulgarian traditional nutrition pattern during the centuries. Geographical location, socio-economical and agricultural development, religion, seasonal variations of the climate played significant role in this process (70).

Archaeological and historical sources point out that the main part of the diet of Thracians was natural rough plant-derived food. Slavs were the largest population in the Balkans. Thanks to the fact that their main livelihood was agriculture, their diet was rich in different varieties of grains, legumes and vegetables. Millet, oats, rye and wheat, cabbage, carrots, turnips, lentils and peas are some of the varieties remained until today as traditional foods in the Balkan region. Bulgars as semi-nomads consumed mainly meat and there is a lack of data about their contribution to our traditional nutrition $(55,70,100)$. 
Milka Nashar, Diana Ivanova

\begin{tabular}{|c|c|c|c|c|c|c|c|}
\hline 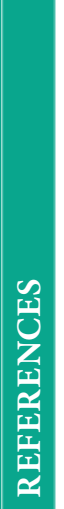 & 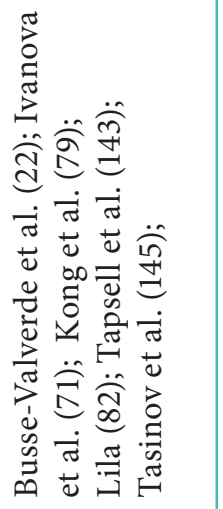 & 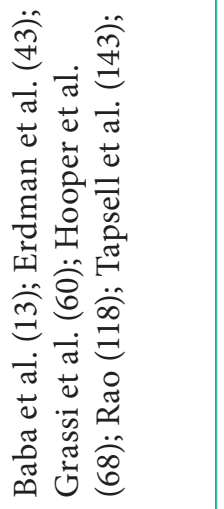 & 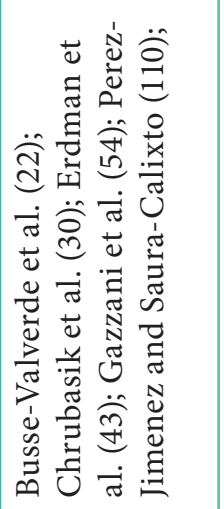 & 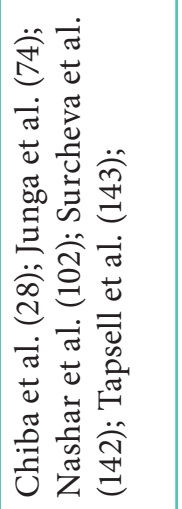 & 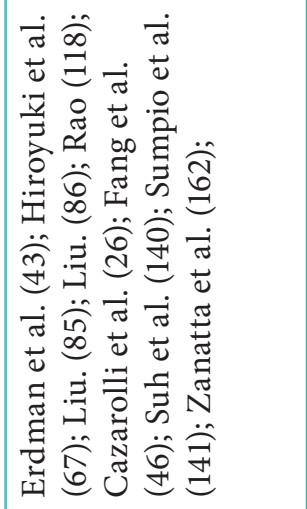 & 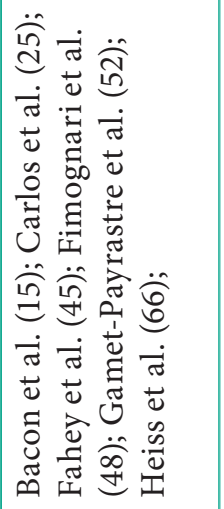 & 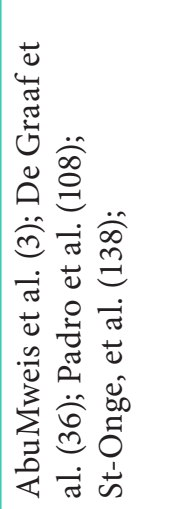 \\
\hline 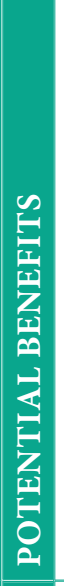 & 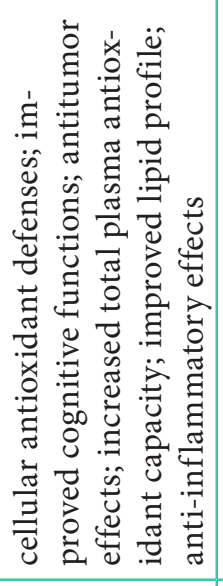 & 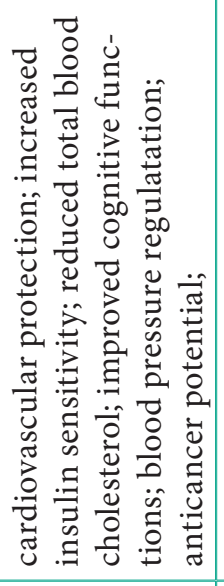 & 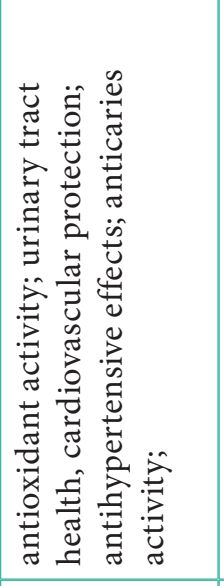 & 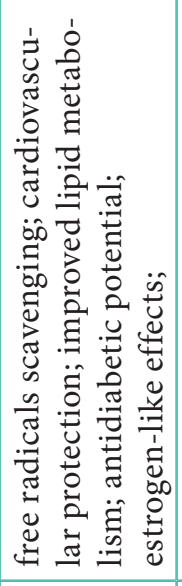 & 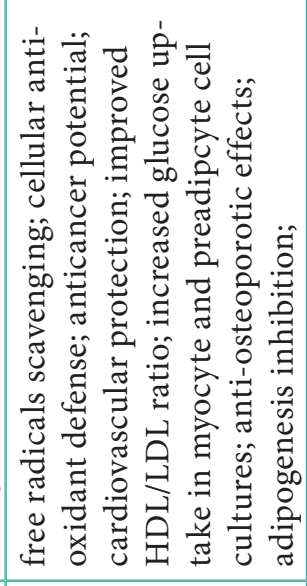 & 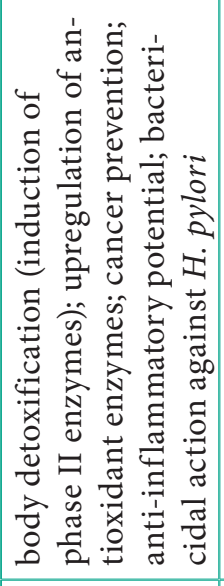 & 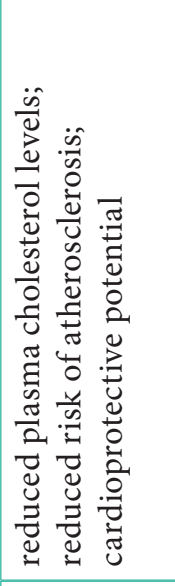 \\
\hline 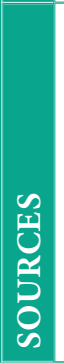 & 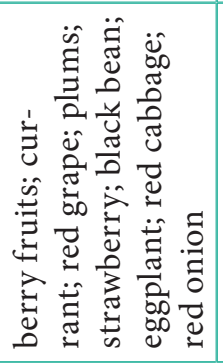 & 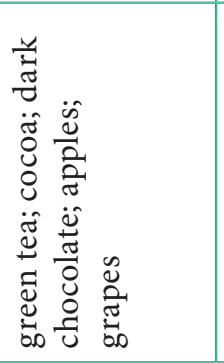 & 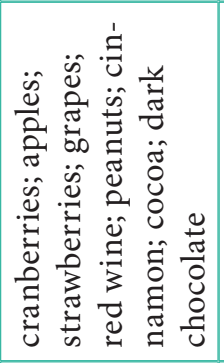 & 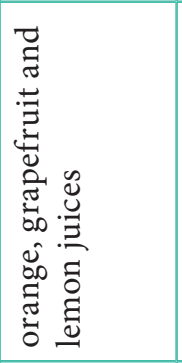 & 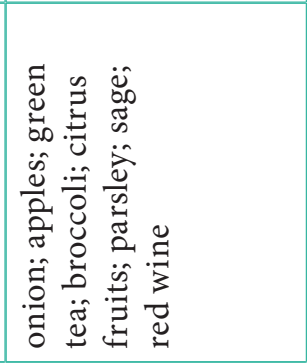 & 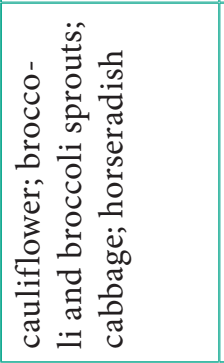 & 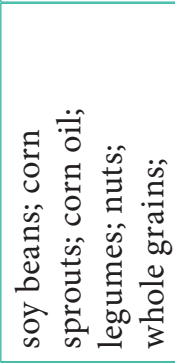 \\
\hline 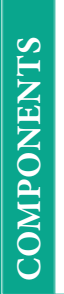 & 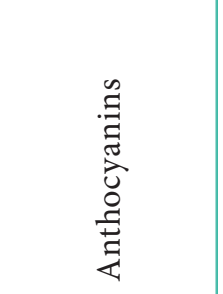 & 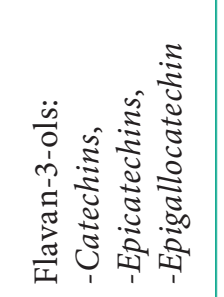 & 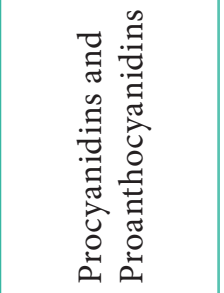 & 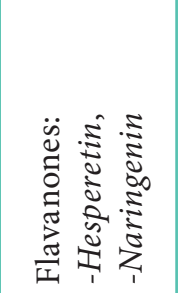 & 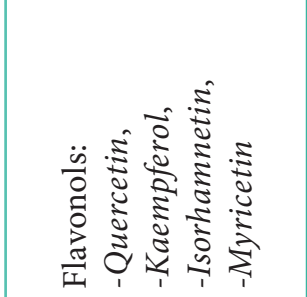 & 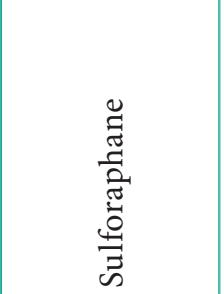 & 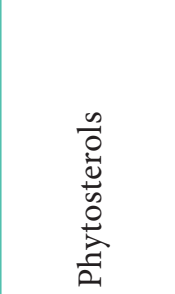 \\
\hline 岕 & & & 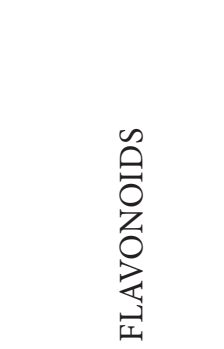 & & & 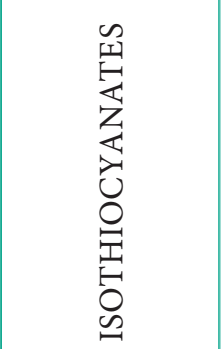 & 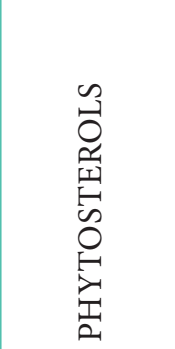 \\
\hline
\end{tabular}

Scripta Scientifica Pharmaceutica, vol. 2, №1, 2015, pp. 15-28

Copyright @ Medical University of Varna 
Functional foods: the new concept emerging from the traditional nutrition

\begin{tabular}{|c|c|c|c|c|c|}
\hline 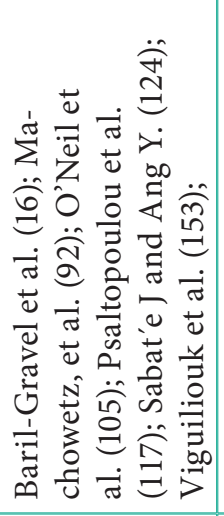 & 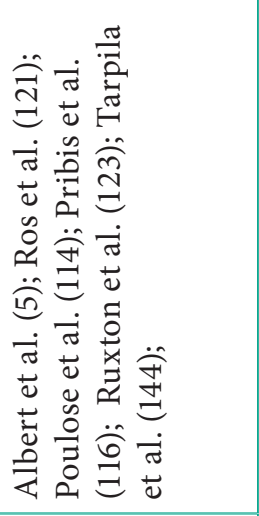 & 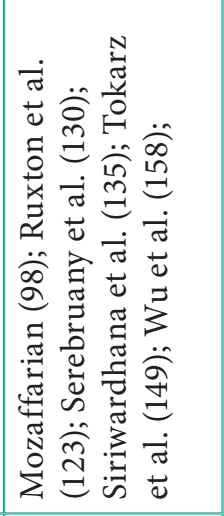 & 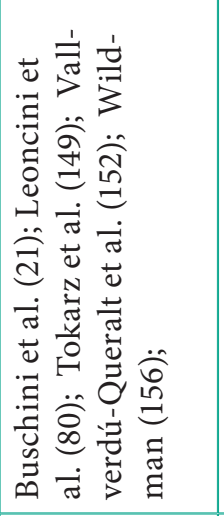 & 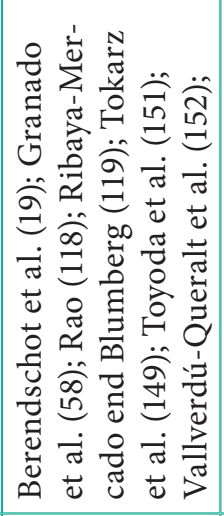 & 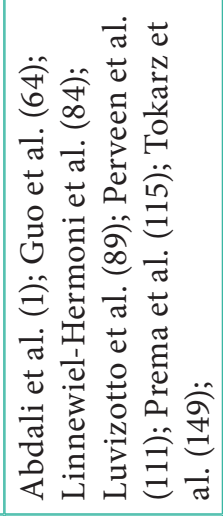 \\
\hline 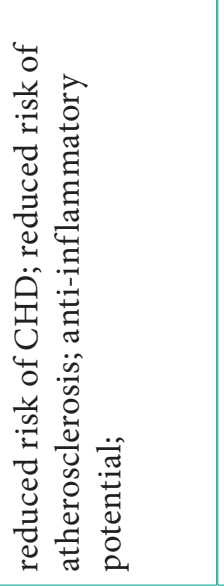 & 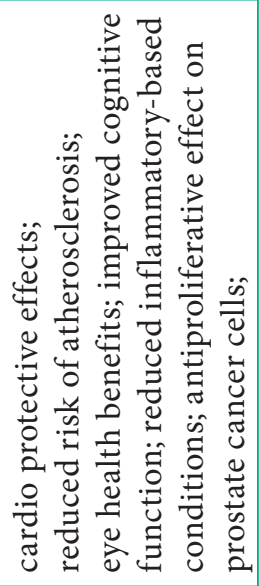 & 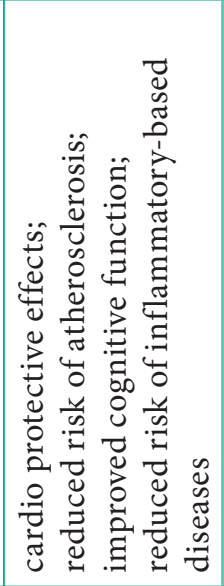 & 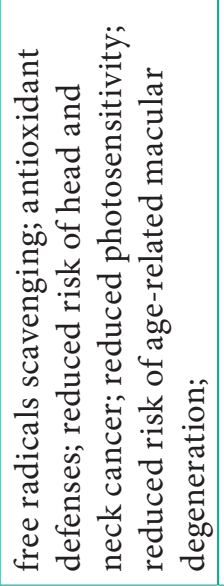 & 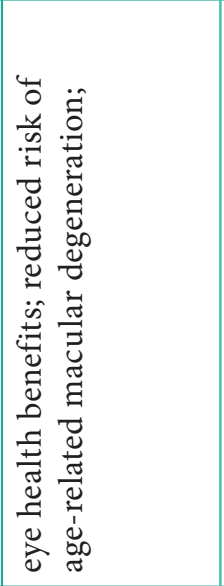 & 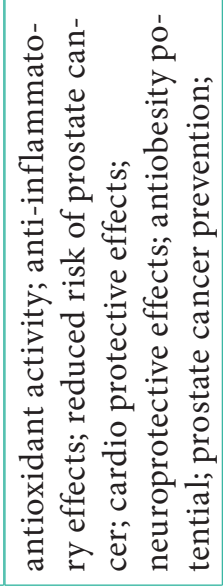 \\
\hline 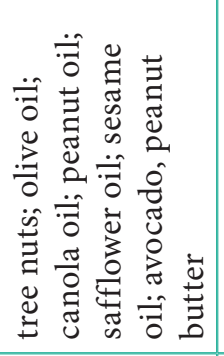 & 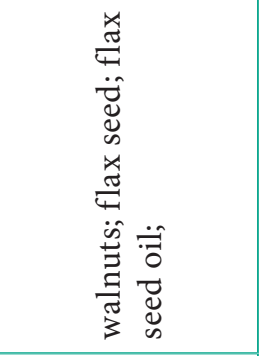 & 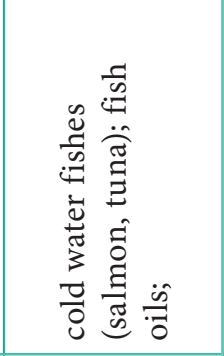 & 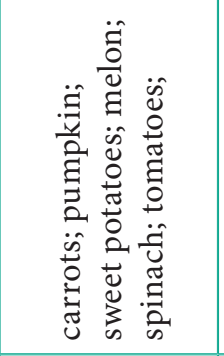 & 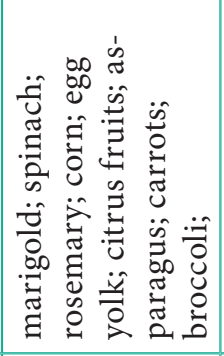 & 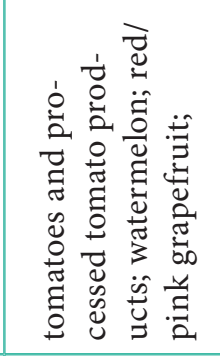 \\
\hline 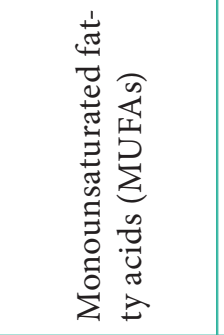 & 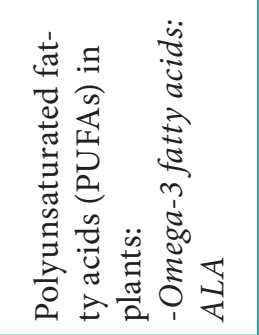 & 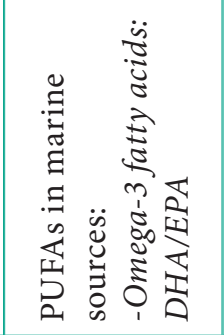 & 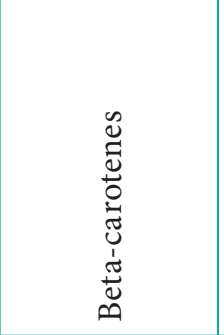 & 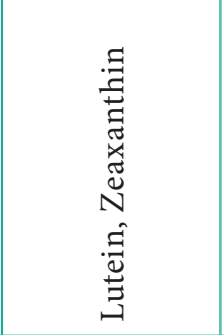 & 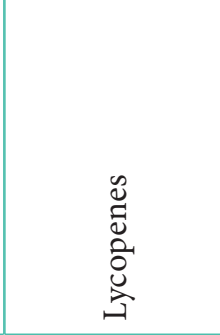 \\
\hline & 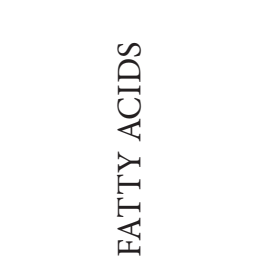 & & & 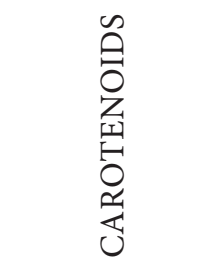 & \\
\hline
\end{tabular}




\begin{tabular}{|c|c|c|c|}
\hline 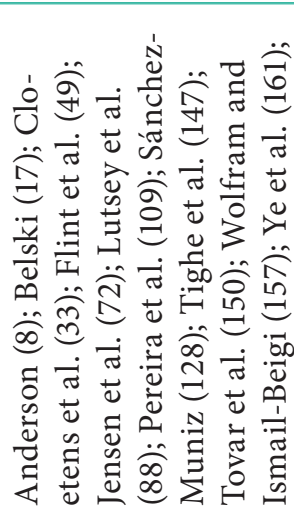 & 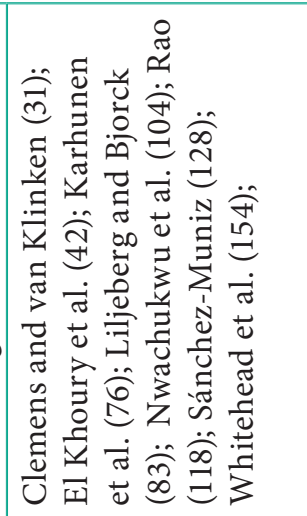 & 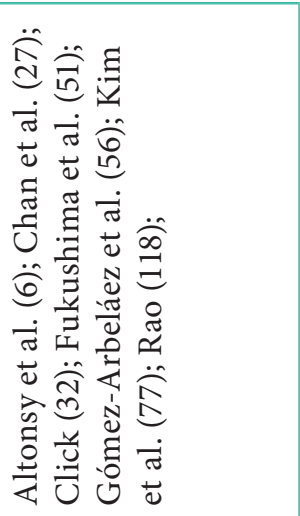 & 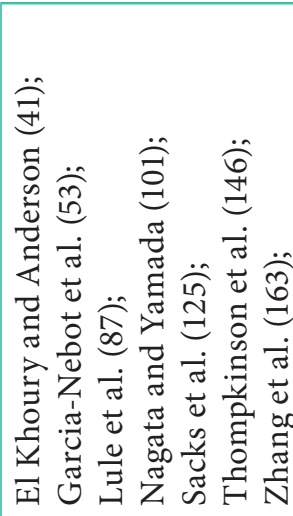 \\
\hline 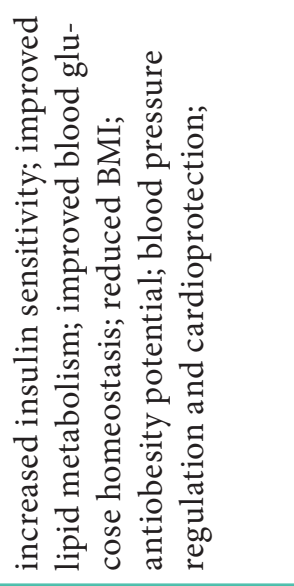 & 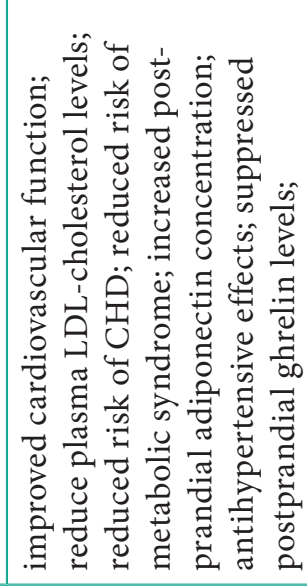 & 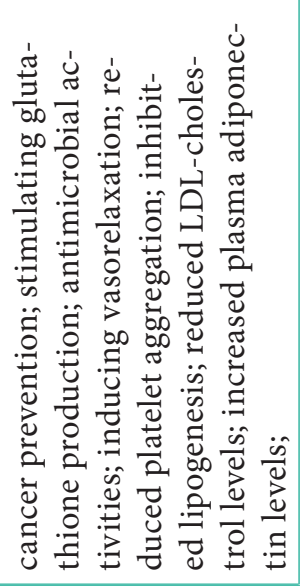 & 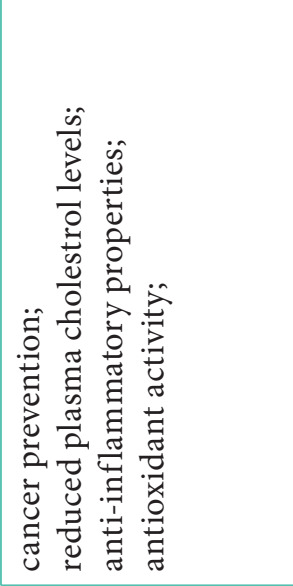 \\
\hline 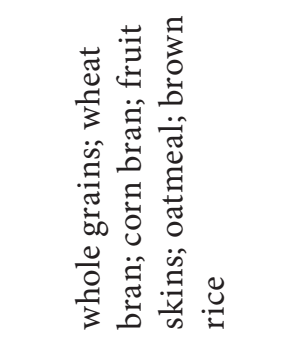 & 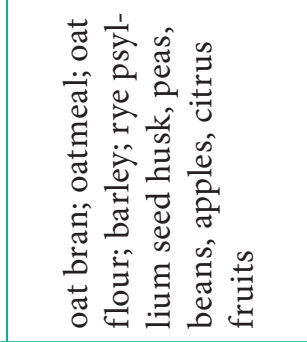 & 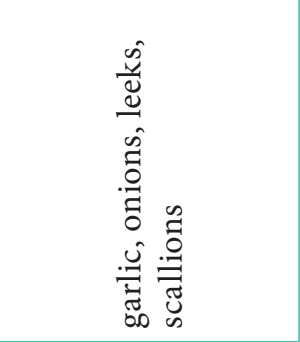 & 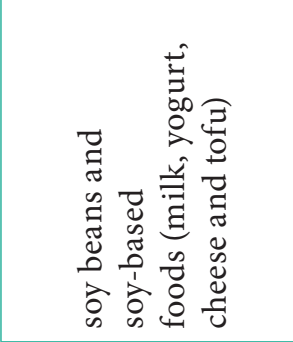 \\
\hline 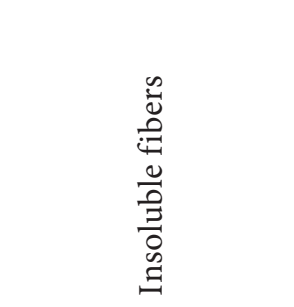 & 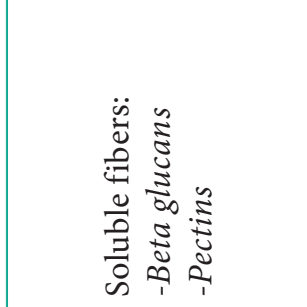 & 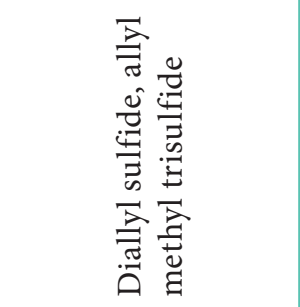 & 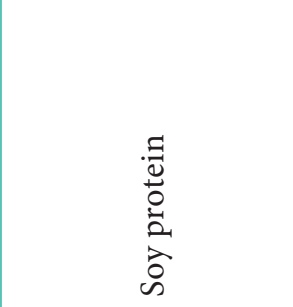 \\
\hline \multicolumn{2}{|c|}{ 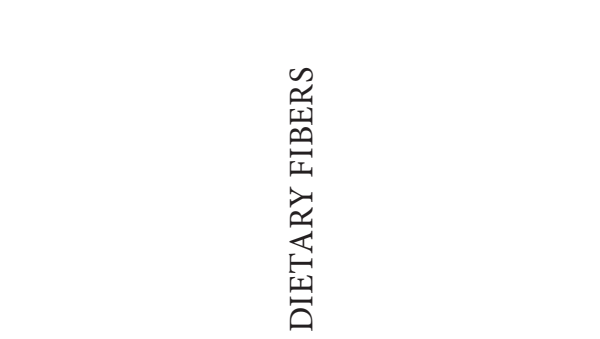 } & 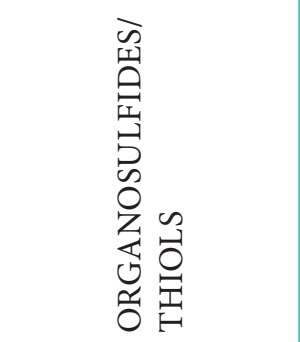 & 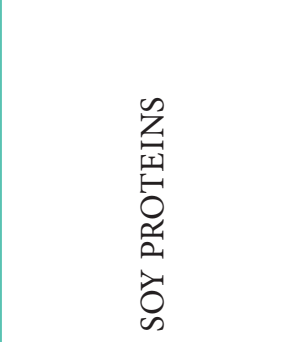 \\
\hline
\end{tabular}

Scripta Scientifica Pharmaceutica, vol. 2, №1, 2015, pp. 15-28 
Functional foods: the new concept emerging from the traditional nutrition

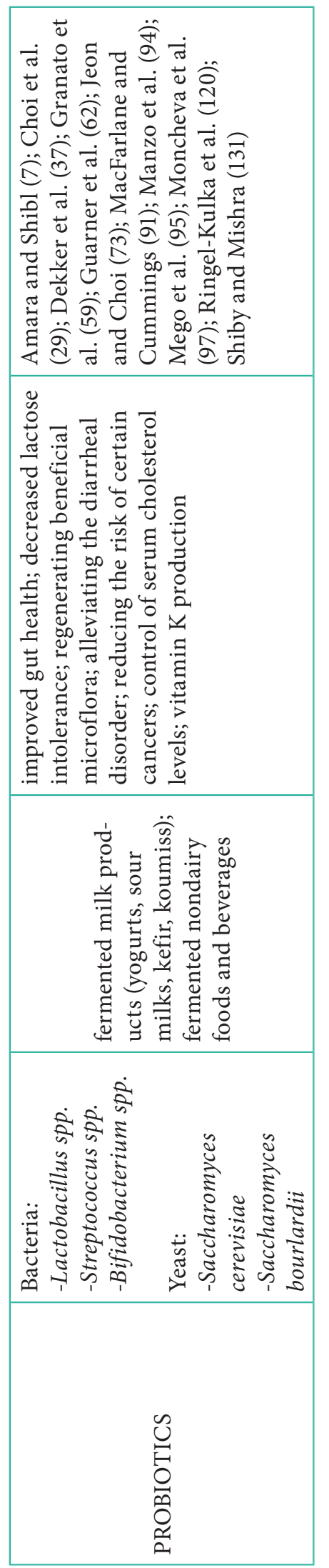

Grains and whole grain foods

Historical sources indicate that a major part of the Thracians' diet was comprised of cereals: barley, millet (sorghum), oats and wheat. It is worth mentioning that Thracians cultivated the wheat variety Triticum spelta (spelt) which is one of the oldest cultivated crops in human history (55). In recent years there is a rising interest in this plant based on the strong evidences about its nutritional value. Along with carbohydrates, spelt grains are very rich in fibers, proteins, vitamins, especially folic acid, and wide range of minerals. Moreover, spelt contains $40 \%$ less phytic acid compared to other wheat varieties. This could contribute to better intestinal bioavailability of spelt derived-minerals as the presence of phytic acid is associated with the chelation processes $(122,139)$. Based on these data spelt could be considered as a functional food with high potential in regulating body metabolism and thus contributing to maintain the healthy phenotype.

Nowadays, the whole grain foods and products are well known as functional foods rich in dietary fibers, regulating lipid metabolism and blood glucose levels and their consumption could be associated with lower risk of type 2 diabetes, cardiovascular diseases and obesity $(8,17,33,109,127,147,150,157,161)$.

Fruits

Because of the climate specificity and the seasonal nature of the fruits our ancestors prepared sun dried fruits such as apples, plums and pears. It is worthy to pay a special attention on prunes (dried plums) which nowadays are considered to be a functional food because of their mild laxative effect due to the high sorbitol content $(38,81,136)$. Several studies revealed the phytochemical composition as well as the health effects of these dried fruits $(136,137)$. Although, prunes are rich in simple sugars their consumption does not increase the blood sugar concentration, probably because of high fiber (approximately 60\%), fructose, and sorbitol content (38). Moreover, they contain large amount of phenolic compounds mainly neochlorogenic and chlorogenic acids which are found to inhibit LDL oxidation (137). These data reveal the antidiabetic, antiobesity and cardioprotective potential of dried prunes. Scientific reports in recent years suggested that prunes consumption could be very efficient in both preventing and revers- 
ing bone loss and could play a role in prevention and management of osteoporosis $(11,69,136)$.

\section{Beverages}

Wine had a prominent place both in everyday life and in the ceremonial rites from the Thracians' time until now (55). Scientific reports suggested that moderate consumption of red wine could be associated with many beneficial effects in cardiovascular diseases, diabetes, osteoporosis and longevity, probably due to the large quantity of polyphenols, especially resveratrol which is the major active compound in this beverage $(12,22,99,113)$.

Historical sources indicate that Thracians prepared special beverages from fermented grains: "briton", made from fermented barley and "parabia" - a mixture of fermented millet and aromatic herbs $(55,70)$.

Another beverage made from fermented cereals and remained traditional so far is "boza". It is a product based on spontaneous fermentation of cereals caused by lactic acid bacteria and yeasts (97). Several studies report that beverages made from fermented grains are source of probiotics and could maintain the gut function. Furthermore, it was estimated that extracted ferments could regulate HDL/total cholesterol ratio, suggesting an antiobesity potential $(29,73)$. The fermented nondairy foods and beverages are considered as appropriate foods in cases of lactose intolerance (59).

\section{Wild plants}

Archeological and historical evidences exist that Thracians were familiar with many herbs and medicinal plants which were used in the healing rituals (148). Since the ancient ages until now our knowledge about the healing properties of many traditional plants was enriched $(39,103)$. Accumulated scientific data in recent decades identified many of the functional components of the medicinal plants as well as some of the mechanisms of the beneficial effects reported by the folk medicine $(18,112,129)$. Most of these benefits seem to be due to the plant polyphenols, reviewed in table 1.

Thracians used the small, rounded corms of water chestnut (Trapa natans) to prepare sweet bread. Except rich in starch, the phytochemical composition of this plant is characterized with significant amount of free amino acids, vitamins, minerals and polyphenols $(45,75)$. Its health benefits are based on wide range of biochemical and pharmacological effects widely reviewed by Adkar et al. (4). Imunomodulatory, neuroprotective and antiulcer potential as well as antiinflammatory, antibacterial and antifungal action are some of the documented properties of water chestnut preparations. Recently, a significant potential of the plant to reduce blood glucose and serum insulin levels was estimated revealing its antidiabetic properties $(35,160)$.

\section{Milk and dairy}

Since ancient times milk had a special place in the diet of Bulgarians $(70,100)$. Bulgarian yogurt (sour milk) is a food known worldwide for its nutritional characteristics and health benefits. In the beginning of the $20^{\text {th }}$ century the Bulgarian student in medicine Stamen Grigorov discovered the bacteria that caused the fermentation in the sour milk (61). The beginning of extensive research on the unique nutritional characteristics of the Bulgarian sour milk was several years later when Mechnikov and coworkers developed the theory of relationship between the increased life expectancy of the Bulgarians and the consumption of the sour milk $(55,70)$. Several studies reported that this bacteria, currently known as Lactobacillus delbrueckii subsp. bulgaricus, possesses strong antimicrobial properties and ability to form colonies in the human intestines suggesting a potential probiotic function $(2,63,96)$. Studies demonstrated that consumption of yoghurt containing viable $L$. delbrueckii and S. thermophilus improved lactose digestion and decreased lactose intolerance $(62,131)$. The Bulgarian sour milk could be considered as a product with functional characteristics based on the scientific data that probiotic foods may modulate gut microbial composition, thereby improving the gut health $(37,57,120)$.

\section{CONCLUSION}

The present study does not claim to cover all aspects of traditional nutrition of Bulgarians. However, scientific data confirmed the functional characteristics of many of the foods included in the traditional diet. Based on this we concluded that the nutrition of our ancestors during the centuries could be positively associated with longevity and reduced risk of chronic diseases and obesity. Based on the alarming data about the overall health status of Bulgarian nation more attention should be paid on improving our 
nutritional habits by adopting the old traditional dietary pattern.

\section{REFERENCES}

1. Abdali D, Samson SE, Grover AK. How effective are antioxidant supplements in obesity and diabetes? Med Princ Pract. 2015; 24:201-215.

2. Abedi D, Feizizadeh S, Akbari V, Jafarian-Dehkordi A. In vitro anti-bacterial and anti-adherence effects of Lactobacillus delbrueckii subsp bulgaricus on Escherichia coli. Res Pharm Sci. 2013; 8(4): 260-268.

3. AbuMweis SS, Marinangeli CP, Frohlich J, Jones PJ. Implementing phytosterols into medical practice as a cholesterol-lowering strategy: overview of efficacy, effectiveness, and safety. Can J Cardiol. 2014;30(10):1225-32.

4. Adkar P, Dongare A, Ambavade S, Bhaskar VH. Trapa bispinosa Roxb: A Review on Nutritional and Pharmacological Aspects. Adv Pharmacol Sci 2014 (2014), Article ID 959830, 13 pages (http://dx.doi. org/10.1155/2014/959830).

5. Albert CM, Michael Gaziano J, Willett WC, Manson JE. Nut consumption and decreased risk of sudden cardiac death in the physicians' health study. Arch Int Med 2002; 162 (12): 1382-1387.

6. Altonsy MO, Habib TN, Andrews SC. Diallyl disulfide-induced apoptosis in a breast-cancer cell line (MCF-7) may be caused by inhibition of histone deacetylation. Nutr Cancer. 2012;64(8):1251-60.

7. Amara AA, Shibl A. Role of Probiotics in health improvement, infection control and disease treatment and management. Saudi Pharm J. 2015;23(2):107-14.

8. Anderson JW. Whole grains protect against atherosclerotic cardiovascular disease. Proc Nutr Soc. 2003;62(1):135-42.

9. Ansari W, Stock C, Mikolajczyk R. Relationships between food consumption and living arrangements among university students in four European countries - A cross-sectional study. Nutrition Journal. 2012, 11:28.

10. Arai S. Studies on functional foods in Japanstate of the art. Biosci Biotechnol Biochem. 1996;60(1):9-15.

11. Arjmandi BH, Khalil DA, Lucas EA, Georgis A, Stoecker BJ, Hardin C, Payton ME, Wild RA. Dried plums improve indices of bone formation in post- menopausal women. J Womens Health Gend Based Med. 2002; 11(1):61-8.

12. Artero A, Artero A, Tarín JJ, Cano A The impact of moderate wine consumption on health. Maturitas. 2015;80(1):3-13.

13. Baba S, Natsume M, Yasuda A et al. Plasma LDL and HDL cholesterol and oxidized LDL concentrations are altered in normo- and hypercholesterolemic humans after intake of different levels of cocoa powder. J Nutr 2007; 137(6):1436-1441.

14. Bach-Faig A, Berry EM, Lairon D, Reguant J, Trichopoulou A, Dernini S, et al. Mediterranean diet pyramid today. Science and cultural updates. Public Health Nutr. 2011;14(12A):2274-84.

15. Bacon JR, Williamson G, Garner RC, Lappin G, Langouët S, Bao Y Sulforaphane and quercetin modulate PhIP-DNA adduct formation in human HepG2 cells and hepatocytes. Carcinogenesis. 2003;24(12):1903-11.

16. Baril-Gravel L, Labonté ME, Couture P, Vohl MC, Charest A, Guay V, et al. Docosahexaenoic acidenriched canola oil increases adiponectin concentrations: a randomized crossover controlled intervention trial. Nutr Metab Cardiovasc Dis. 2015; 25(1):52-9

17. Belski R. Fiber, protein, and lupin-enriched foods: role for improving cardiovascular health. Adv Food Nutr Res. 2012;66:147-215.

18. Benzie IFF, Wachtel-Galor S (Editors). Herbal Medicine: Biomolecular and Clinical Aspects (2nd ed). Boca Raton (FL): CRC Press; 2011.

19. Berendschot TT, Goldbohm RA, Klöpping WA, van de Kraats J, van Norel J, van Norren D. Influence of lutein supplementation on macular pigment, assessed with two objective techniques. Invest. Ophthalmol. Vis. Sci., 41 (11): 3322-6 (2000).

20. Brader L, Uusitupa M, Dragsted LO, Hermansen K. Effects of an isocaloric healthy Nordic diet on ambulatory blood pressure in metabolic syndrome: a randomized SYSDIET sub-study. EJ Clin Nutr. 2014;68:57-63.

21. Buschini E, Fea AM, Lavia CA, Nassisi M, Pignata G, Zola M, Grignolo FM. Recent developments in the management of dry age-related macular degeneration. Clin Ophthalmol. 2015;9:563-74.

22. Busse-Valverde N, Gómez-Plaza E, López-Roca JM, Gil-Muñoz R, Bautista-Ortín AB. The extraction of anthocyanins and proanthocyanidins from grapes to wine during fermentative maceration is affect- 
ed by the enological technique. J Agric Food Chem. 2011;59(10):5450-5455

23. Calton EK, James AP, Pannu PK, Soares MJ. Certain dietary patterns are beneficial for the metabolic syndrome: reviewing the evidence. Nutr Res. 2014;34(7):559-68.

24. Cambie RC, Ferguson LR. Potential functional foods in the traditional Maori diet. Mutat Res. 2003; 523-524:109-17.

25. Carlos Enrique Guerrero-Beltrána, Mariel Calderón-Olivera, José Pedraza-Chaverria, Yolanda Irasema Chirinob. Protective effect of sulforaphane against oxidative stress: Recent advances. Experimental and Toxicologic Pathology. 2012;64:503-508.

26. Cazarolli LH, Folador P, Pizzolatti MG, Mena Barreto Silva FR. Signaling pathways of kaempferol3-neohesperidoside in glycogen synthesis in rat soleus muscle. Biochimie. 2009;91(7):843-9.

27. Chan JY, Yuen AC, Chan RY, Chan SW.A review of the cardiovascular benefits and antioxidant properties of allicin. Phytother Res. 2013;27(5):637-46.

28. Chiba H, Uehara M, Wu J, Wang X, Masuyama R, Suzuki K et al. Hesperidin, a citrus flavonoid, inhibits bone loss and decreases serum and hepatic lipids in ovariectomized mice. J Nutr 2003; 133(6):1892-1897.

29. Choi YM, Bae SH, Kang DH, Suh HJ. Hypolipidemic effect of lactobacillus ferment as a functional food supplement. Phytother Res. 2006;20(12):1056-60.

30. Chrubasik C, Li G, Chrubasik S. The clinical effectiveness of chokeberry: a systematic review. Phytother Res. 2010;24(8):1107-14.

31. Clemens R, van Klinken BJ. The future of oats in the food and health continuum. Br J Nutr. 2014;112 Suppl 2:S75-9.

32. Click RE. Anticancer activity and chemoprevention of xenobiotic organosulfurs in preclinical model systems. Oncol Discov. 2013;1(4).

33. Cloetens L, Ulmius M, Johansson-Persson A, Akesson B, Onning G. Role of dietary beta-glucans in the prevention of the metabolic syndrome. Nutr Rev. 2012;70(8):444-458.

34. Cordain L, Eaton SB, Sebastian A, Mann N, Lindeberg S, Watkins BA, O'Keefe JH, Brand-Miller J. Origins and evolution of the Western diet: health implications for the 21st century. Am J Clin Nutr. 2005;81:341-54.

35. Das PK, Bhattacharya S, Pandey JN, Biswas M. Antidiabetic activity of Trapa natans fruit peel extract against streptozotocin induced diabetic rats. Global J Pharmacol. 2010;5(3):186-190.

36. De Graaf J, De Sauvage Nolting PR, Van Dam M, Belsey EM, Kastelein JJ, Haydn Pritchard P and Stalenhoef AF, Consumption of tall oil-derived phytosterols in a chocolate matrix significantly decreases plasma total and low-density lipoproteincholesterol levels. Br J Nutr. 2002;(5):479-88.

37. Dekker J, Collett M, Prasad J, Gopal P. Functionality of probiotics - potential for product development. Forum Nutr. 2007;60:196-208.

38. 38. Dikeman CL, Bauer LL, Fahey GC Jr. Carbohydrate composition of selected plum/prune preparations. J Agric Food Chem. 2004;52:853-859.

39. Dimkov P. Bulgarian Folk Medicine. ed. by S. Todorov. Sofia: Izdatelstvo BAN; 1993. Bulgarian.

40. Doyon M, Labrecque JA. Functional foods: a conceptual definition. British Food J. 2008;110(11):1133-1149.

41. El Khoury D, Anderson GH. Recent advances in dietary proteins and lipid metabolism. Curr Opin Lipidol. 2013;24(3):207-13.

42. El Khoury D, Cuda C, Luhovyy BL, Anderson GH. Beta glucan: health benefits in obesity and metabolic syndrome. J Nutr Metab. 2012;2012:851362.

43. Erdman JW Jr, Balentine D, Arab L, Beecher G, Dwyer JT, Folts J, Harnly J, Hollman P, Keen CL, Mazza G, Messina M, Scalbert A, Vita J, Williamson G, Burrowes J. Flavonoids and heart health: proceedings of the ILSI North America Flavonoids Workshop, May 31-June 1, 2005, Washington, DC. J Nutr. 2007;137(3 Suppl 1):718S-737S.

44. European Comission, Directorate - General for Research, Directorate E - Biotechnologies, Agriculture, Foods, 24194 EN, 2010. Functional foods.

45. Fahey JW, Haristoy X, Dolan PM, Kensler TW, Scholtus I, Stephenson KK, et al. Sulforaphane inhibits extracellular, intracellular, and antibiotic-resistant strains of Helicobacter pylori and prevents benzo[a]pyrene-induced stomach tumors. Proc Natl Acad Sci U S A. 2002;99(11):7610-5.

46. Fang XK, Gao J, Zhu DN.Kaempferol and quercetin isolated from Euonymus alatus improve glucose 
Functional foods: the new concept emerging from the traditional nutrition

uptake of 3T3-L1 cells without adipogenesis activity. Life Sci. 2008;82(11-12):615-22.

47. Faruk MO, Amin MZ, Sana NK, Shaha RK, Biswas KK. Biochemical analysis of two varieties of water chestnuts (Trapa sp.). Pak J Biol Sci. 2012;15(21):1019-26.

48. Fimognari C, Nüsse M, Cesari R, Iori R, CantelliForti G, Hrelia P. Growth inhibition, cell-cycle arrest and apoptosis in human T-cell leukemia by the isothiocyanate sulforaphane. Carcinogenesis 2002;23(4):581-6.

49. Flint AJ, Hu FB, Glynn RJ et al. Whole grains and incident hypertension in men. Am J Clin Nutr. 2009;90(3):493-498.

50. Frank B. Hu. Dietary pattern analysis: a new direction in nutritional epidemiology. Curr Opin Lipidol. 2002;13:3-9.

51. Fukushima S, Takada N, Hori T, Wanibuchi H. Cancer prevention by organosulfur compounds from garlic and onion. J Cell Biochem Suppl. 1997;27:100-5.

52. Gamet-Payrastre L, Li P, Lumeau S, Cassar G, Dupont MA, Chevolleau S, Gasc N, Tulliez J, Tercé F. Sulforaphane, a naturally occurring isothiocyanate, induces cell cycle arrest and apoptosis in HT29 human colon cancer cells. Cancer Res. 2000;60(5):1426-33.

53. Garcia-Nebot MJ, Recio I, Hernandez-Ledesma B. Antioxidant activity and protective effects of peptide lunasin against oxidative stress in intestinal Caco-2 cells. Food Chem Toxicol. 2014;65:155-61.

54. Gazzani G, Daglia M, Papetti A. Food components with anticaries activity. Curr Opin Biotechnol. 2012;23(2):153-9.

55. Goev A (Editor). Food sacred and profane. Faber Publ.; 2014.

56. Gómez-Arbeláez D, Lahera V, Oubiña P, ValeroMuñoz M, de Las Heras N, Rodríguez Y, García RG et al. Aged garlic extract improves adiponectin levels in subjects with metabolic syndrome: a doubleblind, placebo-controlled, randomized, crossover study. Mediators Inflamm. 2013;2013:285795.

57. Gorbach SL. Lactic acid bacteria and human health. Ann Med. 1990; 22(1):37-41.

58. Granado F, Olmedilla B, Blanco I. Nutritional and clinical relevance of lutein in human health. Br J Nutr. 2003;90(3):487-502.
59. Granato D, Branco GF, Nazzaro F, Cruz AG, Faria JAF. Functional foods and nondairy probiotic food development: trends, concepts, and products. Comp Rev Food Sci Food Safety 2010; (9):292-302.

60. Grassi D, Lippi C, Necozione S, Desideri G, Ferri C. Short-term administration of dark chocolate is followed by a significant increase in insulin sensitivity and a decrease in blood pressure in healthy persons. Am J Clin Nutr 2005;81(3):611-614.

61. Grigoroff, St. Étude sur une lait fermentée comestible. Le "Kissélo mléko" de Bulgarie. Rev Med Suisse Romande. 1905.

62. Guarner F, Perdigon G, Corthier G, Salminen S, Koletzko B, Morelli L. Should yoghurt cultures be considered probiotic? Br J Nutr. 2005; 93(6):783-6.

63. Guglielmotti DM, Marcó MB, Golowczyc M, Reinheimer JA, Quiberoni AL. Probiotic potential of Lactobacillus delbrueckii strains and their phage resistant mutants. Int Dairy J. 2007;17:916-925.

64. Guo Y, Liu Y, Wang Y. Beneficial effect of lycopene on anti-diabetic nephropathy through diminishing inflammatory response and oxidative stress. Food Funct. 2015;6(4):1150-6.

65. Hasler CM. Functional Foods: Their role in disease prevention and health promotion. A publicationof the institute of food technologists ' expert panel on food safety and nutrition 1998;52(11):63-70.

66. Heiss E, Herhaus C, Klimo K, Bartsch H, Gerhäuser C. Nuclear factor kappa B is a molecular target for sulforaphane-mediated anti-inflammatory mechanisms. J Biol Chem 2001;276(34):32008-15.

67. Hiroyuki S, Yoshinori H, Satoshi N, Hitoshi A, Kazuki K, Simultaneous determination of all polyphenols in vegetables, fruits, and teas. J Agric Food Chem. 2003;51(3):571-581.

68. Hooper L, Kroon PA, Rimm EB et al. Flavonoids, flavonoid-rich foods and cardiovascular risk: a meta-analysis of randomized controlled trials. Am J Clin Nutr. 2008;88(1):38-50.

69. Hooshmand S, Arjmandi BH. Viewpoint: dried plum, an emerging functional food that may effectively improve bone health. Ageing Res Rev. 2009;8(2):122-7.

70. Hristov D. Role of traditional Bulgarian food from the past. Health Sci. 2014;3(15):31-33.

71. Ivanova D, Tasinov O, Kiselova-Kaneva Y. Improved lipid profile and increased serum antioxidant capacity in healthy volunteers after Sambucus 
ebulus L. fruit infusion consumption. Int J Food Sci Nutr. 2014;65(6):740-744.

72. Jensen MK, Koh-Banerjee P, Hu FB et al. Intakes of whole grains, bran, and germ and the risk of coronary heart disease in men. Am J Clin Nutr. 2004;80(6):1492-1499.

73. Jeon JR, Choi JH. Lactic acid fermentation of germinated barley fiber and proliferative function of colonic epithelial cells in loperamide-induced rats. J Med Food. 2010;13(4):950-60.

74. Junga UJ, Leeb MK, Parkc YB, Kangc MA, Choi MS. Effect of citrus flavonoids on lipid metabolism and glucose-regulating enzyme mRNA levels in type-2 diabetic mice. Int J Biochem Cell Biol. 2006;38(7):1134-1145.

75. Karg S. The water chestnut (Trapa natans L.) as a food resource during the 4 th to 1st millennia $\mathrm{BC}$ at Lake Federsee, Bad Buchau (southern Germany). Environmental Archaeology. 2006;11(1):125-130.

76. Karhunen LJ, Flander S, Liukkonen KH et al. Fiber effectively inhibits postprandial decrease in plasma ghrelin concentration. Abstr Obes Rev. 2005;6:p. 59.

77. Kim I, Kim HR, Kim JH, Om AS. Beneficial effects of Allium sativum L. stem extract on lipid metabolism and antioxidant status in obese mice fed a high-fat diet. J Sci Food Agric. 2013;93(11):2749-57.

78. Kolehmainen M, Ulven SM, Paananen J, de Mello V, Schwab U, Carlberg C et al. Healthy Nordic diet downregulates the expression of genes involved in inflammation in subcutaneous adipose tissue in individuals with features of the metabolic syndrome. Am J Clin Nutr. 2015;101(1):228-39.

79. Kong JM, Chia LS, Goh NK, Chia TF, Brouillard R. Analysis and biological activities of anthocyanins. Phytochem. 2003; 64:923-933.

80. Leoncini E, Nedovic D, Panic N, Pastorino R, Edefonti V, Boccia S. Carotenoid intakes from natural sources and head and neck cancer: a systematic review and meta-analysis of epidemiological studies. Cancer Epidemiol Biomarkers Prev. 2015 [Epub ahead of print]

81. Lever E, Cole J, Scott SM, Emery PW, Whelan K. Systematic review: the effect of prunes on gastrointestinal function. Aliment Pharmacol Ther. 2014; 40(7):750-8.

82. Lila A. Anthocyanins and Human Health: An In Vitro Investigative Approach. J Biomed Biotechnol. 2004 (5): 306-313.
83. Liljeberg H.and Bjorck I. Effects of a low-glycaemic index spaghetti meal on glucose tolerance and lipaemia at a subsequent meal in healthy subjects. E J Clin Nutr. 2000; 54(1):24-28.

84. Linnewiel-Hermoni $K$, Khanin $M$, Danilenko $M$, Zango G, Amosi Y, Levy J, Sharoni Y. The anti-cancer effects of carotenoids and other phytonutrients resides in their combined activity. Arch Biochem Biophys. 2015;572:28-35.

85. Liu RH. Health benefits of fruit and vegetables are from additive and synergistic combinations of phytochemicals. Am J Clin Nutr 2003; 78 (3); 517S-520S.

86. Liu RH. Potential synergy of phytochemicals in cancer prevention: Mechanism of action. Nutr. 2004; 134 (12): 3479S-3485S.

87. Lule VK, Garg S, Pophaly SD, Hitesh, Tomar SK. Potential health benefits of lunasin: a multifaceted soy-derived bioactive peptide. J Food Sci. 2015;80(3):R485-94.

88. Lutsey PL, Jacobs DR, Kori S et al., Whole grain intake and its cross-sectional association with obesity, insulin resistance, inflammation, diabetes and subclinical CVD: the MESA Study. Br J Nutr. 2007; 98 (2): 397-405.

89. Luvizotto R, Nascimento A, Miranda N, Wang XD, Ferreira A. Lycopene-rich tomato oleoresin modulates plasma adiponectin concentration and $\mathrm{mRNA}$ levels of adiponectin, SIRT1, and FoxO1 in adipose tissue of obese rats. Hum Exp Toxicol. 2015; pii: 0960327114551395 [Epub ahead of print]

90. MacDonald L, Foster BC, Akhtar H. Food and therapeutic product interactions - a therapeutic perspective. J Pharm Pharm Sci. 2009;12(3):367-77.

91. MacFarlane GT, Cummings JH Probiotics, infection and immunity. Cur. Opin Infect Dis. 2002;15:501-506.

92. Machowetz A, Poulsen HE, Gruendel S, Weimann A, Fitz M, Marrugat J. Effect of olive oils on biomarkers of oxidative DNA stress in Northern and Southern Europeans. FASEB J. 2007; 21:45-52.

93. Madovsky P, Sara A, Masseria C, Hernandez-Quevedo C, McDaid D, Mossialos E. Health in European Union. Trends and analysis. World Health Organization 2009.

94. Manzo N, Pizzolongo F, Montefusco I, Aponte M, Blaiotta G, Romano R. The effects of probiotics and prebiotics on the fatty acid profile and conjugated 
Functional foods: the new concept emerging from the traditional nutrition

linoleic acid content of fermented cow milk. Int J Food Sci Nutr. 2015; 6:1-6.

95. Mego M, Majek J, Koncekova R, Ebringer L, Ciernikova S, Rauko P, Kovac M, Trupl J, Slezak P, Zajac V Intramucosal bacteria in colon cancer and their elimination by probiotic strain Enterococcus faecium M-74 with organic selenium. Folia Microbiol. (Praha) 2005;50:443-447.

96. Mogna L, Del Piano M, Deidda F, Nicola S, Soattini L, Debiaggi R, et al. Assessment of the in vitro inhibitory activity of specific probiotic bacteria against different Escherichia coli strains. J Clin Gastroenterol. 2012; 46 Suppl:S29-32.

97. Moncheva P, Chipeva V, Kujumdzieva A, Ivanova I, Dousset X, Gocheva B The Composition of the Microflora of Boza, an Original Bulgarian Beverage, Biotechnol Biotechnol Equipment 2003;17(1):164-168.

98. Mozaffarian D. Fish and n-3 fatty acids for the prevention of fatal coronary heart disease and sudden cardiac death. Am J Clin Nutr. 2008;87 (6): 1991S-1996S

99. Mulero J, Martínez G, Oliva J, Cermeño S, Cayuela JM, Zafrilla P, Martínez-Cachá A, Barba A. Phenolic compounds and antioxidant activity of red wine made from grapes treated with different fungicides. Food Chem. 2015;180:25-31.

100. Mutafova K, Hristova N, Ivanov I, Georgieva G. Standards of everyday life in the middle ages and in modern times. Faber Publ; 2012.

101. Nagata J, Yamada K. Effects of simultaneous intake of soybean protein and diacylglycerol on lipid profiles and body fat accumulation in rats. Biosci Biotechnol Biochem. 2009;73(6):1328-32.

102. Nashar M, Vlaskovska M, Bozhilova-Pastirova A, Kasakov L. Behavioral and immunohistochemical investigations of the effects of phytoestrogens on pain, analgesia, and inflammation: Gender dependency. Neurophysiology 2006;38 (4):350-353.

103. Nedelcheva A. Medicinal plants from an old Bulgarian medical book. J Med Plants Res. 2012; 6(12):2324-2339.

104. Nwachukwu ID, Devassy JG, Aluko RE, Jones PJ. Cholesterol-lowering properties of oat $\beta$-glucan and the promotion of cardiovascular health: did Health Canada make the right call? Appl Physiol Nutr Metab. 2015 27:1-8.

105. O’Neil CE, Nicklas TA, Fulgoni VL 3rd. Tree nut consumption is associated with better nutrient ad- equacy and diet quality in adults: National Health and Nutrition Examination Survey 2005-2010. Nutrients. 2015;7(1):595-607.

106. Ortega RM. Importance of functional foods in the Mediterranean diet. Publ Health Nutr 2006;9(8A):1136-1140.

107. Özen A, Bibiloni M, Pons A, Tur JA. Consumption of functional foods in Europe; a systematic review. Nutr Hosp. 2014;29(3):470-478.

108. Padro T, Vilahur G, Sánchez-Hernández J, Hernández M, Antonijoan RM4, Perez A, Badimon L .Lipidomic changes of LDL in overweight and moderately hypercholesterolemic subjects taking phytosterol- and omega-3-supplemented milk. J Lipid Res. 2015;56(5):1043-56.

109. Pereira MA, Jacobs DR Jr, Pins JJ, Raatz SK, Gross MD, Slavin JL, Seaquist ER Effect of whole grains on insulin sensitivity in overweight hyperinsulinemic adults. Am J Clin Nutr. 2002;75(5):848-55.

110. Perez-Jimenez J and Saura-Calixto F. Grape products and cardiovascular disease risk factors. Nutr Res Rev. 2008;21(2) 158-173.

111. Perveen R, Suleria HA, Anjum FM, Butt MS, Pasha I, Ahmad S.Tomato (Solanum lycopersicum) carotenoids and lycopenes chemistry; metabolism, absorption, Nutrition, and allied health claimsa comprehensive review. Crit Rev Food Sci Nutr. 2015;55(7):919-29.

112. Phillipson D. Phytochemistry and medicinal plants. Phytochem 2001; 56:237-243.

113. Pollack RM, Crandall JP. Resveratrol: therapeutic potential for improving cardiometabolic health. Am J Hypertens. 2013;26(11):1260-8.

114. Poulose SM, Miller MG, Shukitt-Hale B. Role of walnuts in maintaining brain health with age. J Nutr. 2014;144(4 Suppl):561S-566S.

115. Prema A, Janakiraman U, Manivasagam $T$, Thenmozhi AJ. Neuroprotective effect of lycopene against MPTP induced experimental Parkinson's disease in mice. Neurosci Lett. 2015: S0304-3940(15)00381-X.

116. Pribis P, Bailey RN, Russell AA, Kilsby MA, Hernandez M, Craig WJ, Grajales T, Shavlik DJ, Sabatè J. Effects of walnut consumption on cognitive performance in young adults. Br J Nutr. 2012;107(9):1393-401.

117. Psaltopoulou T, Naska A, Orfanos P, Trichopoulos D, Mountokalakis T, Trichopoulou A. Olive oil, 
the Mediterranean diet, and arterial blood pressure: the Greek European Prospective Investigation into Cancer and Nutrition (EPIC) study. Am J Clin Nutr. 2004;80(4):1012-1018.

118. Rao BN. Bioactive phytochemicals in Indian foods and their potential in health promotion and disease prevention. Asia Pacific J Clin Nutr. 2003;12(1):9-22.

119. Ribaya-Mercado JD, Blumberg JB. Lutein and zeaxanthin and their potential roles in disease prevention. J Am Coll Nutr. 2004;23(6 Suppl):567S-587S.

120. Ringel-Kulka T, Kotch JB, Jensen ET, Savage E, Weber DJ. Randomized, double-blind, placebo-controlled study of synbiotic yogurt effect on the health of children. J Pediatr. 2015 S0022-3476(15)00158-4.

121. Ros E, Nunez I, A. Perez-Heras et al. A walnut diet improves endothelial function in hypercholesterolemic subjects: a randomized crossover trial. Circulation. 2004;109(13):1609-1614.

122. Ruibal-Mendieta NL, Delacroix DL, Mignolet E, Pycke JM, Marques C, Rozenberg R, Petitjean G, Habib-Jiwan JL, Meurens M, Quetin-Leclercq J, Delzenne NM, Larondelle Y Spelt (Triticum aestivum ssp. spelta) as a source of breadmaking flours and bran naturally enriched in oleic acid and minerals but not phytic acid. J Agric Food Chem. 2005;53(7):2751-9

123. Ruxton $\mathrm{CH}$, Reed SC, A. Simpson M J, Millington K. J. The health benefits of omega-3 polyunsaturated fatty acids: a review of the evidence. J Hum Nutr Dietet. 2004;17:pp. 449-459

124. Sabat'e J and Ang Y. Nuts and health outcomes: new epi- demiologic evidence. American Journal of Clinical Nutrition 2009;89(5):1643S-1648S.

125. Sacks FM, Lichtenstein A, Van Horn L, Harris W, Kris-Etherton P, Winston M. Soy protein, isoflavones, and cardiovascular health: An American Heart Association Science Advisory for professionals from the Nutrition Committee. Circulation. 2006;113(7):1034-1044.

126. Sáez-Almendros S, Obrador B, Bach-Faig A and Serra-Majem L. Environmental footprints of Mediterranean versus Western dietary patterns: beyond the health benefits of the Mediterranean diet. Environmental Health. 2013;12:118.

127. Sánchez-Muniz FJ Dietary fibre and cardiovascular health. Nutr Hosp. 2012;27(1):31-45.
128. Sánchez-Muniz FJ. Dietary fibre and cardiovascular health. Nutr Hosp. 2012; 27(1):31-45.

129. Saxena M, Saxena J, Nema R, Singh D, Gupta A. Phytochemistry of medicinal plants. J Pharmacogn Phytochem. 2013;1:168-182.

130. Serebruany VL, Miller M, Pokov AN, Lynch D, Jensen JK, Hallén J, Atar D. Early impact of prescription Omega-3 fatty acids on platelet biomarkers in patients with coronary artery disease and hypertriglyceridemia. Cardiology. 2011;118(3):187-94.

131. Shiby VK, Mishra HN. Fermented milks and milk products as functional foods-a review. Crit Rev Food Sci Nutr. 2013;53(5):482-96

132. Shimizu T. Health claims on functional foods: the Japanese regulations and international comparision. Asia Pac J Clin Nutr. 2003;16:241-252.

133. Shimizu T. Newly established regulation in Japan: foods with health claims. Asia Pac J Clin Nutr. 2002;11(2):S94-96.

134. Simopoulos AP. The Mediterranean diets: what is so special about the diet of Greece. The scientific evidence J. Nutr. 131: 3065S-3073S, 2001;

135. Siriwardhana N, Kalupahana NS, Moustaid-Moussa N. Health benefits of n-3 polyunsaturated fatty acids: eicosapentaenoic acid and docosahexaenoic acid. Adv Food Nutr Res. 2012;65:211-22.

136. Stacewicz - Sapuntzakis M, Bowen PE, Hussain EA, Damayanti Wood BI, Farnsworth NR. Chemical composition and potential health effects of prunes: a functional food? Crit Rev Food Sci Nutr. 2001;41:251-286.

137. Stacewicz-Sapuntzakis M. Dried plums and their products: composition and health effects-an updated review. Crit Rev Food Sci Nutr. 2013;53(12):1277-302.

138. St-Onge MP, Lamarche B, Mauger JF, Jones, Peter JH. Consumption of a functional oil rich in phytosterols and medium-chain triglyceride oil improves plasma lipid profiles in men. J Nutr 2003;133(6):1815-1820.

139. Suchowilska E, Wiwart M, Kandler W, Krska R. A comparison of macro- and microelement concentrations in the whole grain of four Triticum Species. Plant Soil Environ. 2012;58(3):141-147.

140. Suh KS, Choi EM, Kwon M, Chon S, Oh S, Woo JT et al. Kaempferol attenuates 2-deoxy-d-ribose-induced oxidative cell damage in MC3T3-E1 osteoblastic cells. Biol Pharm Bull. 2009;32(4):746-9. 
Functional foods: the new concept emerging from the traditional nutrition

141. Sumpio BE, Cordova AC, Berke-Schlessel DW, Qin F, Chen Q. H. Green tea, the "Asian Paradox" and cardiovascular disease. J Am Coll Surg. 2006; 202 (5): $813-825$.

142. Surcheva Sl, Nashar M, Milev M, Yanev N, Kasakov L, Vlaskovska M. Effect of phytoestrogens and estradiol on pain and analgesic effect of morphine and metamizol. Role of gender and genetic variability. J Bulg Cancer Soc. 2007; 1:51-55.

143. Tapsell LC, Hemphill I, Cobiac L, Patch CS, Sullivan DR, Fenech et al. Health benefits of herbs and spices: the past, the present, the future. Med J Aust. 2006;185(4 Suppl):S4-24.

144. Tarpila A, Wennberg T, Tarpila S. Flaxseed as a functional food. Curr Top Nutraceutical Res. 2005; 3 (3): 167-188.

145. Tasinov O, Kiselova-Kaneva Y, Ivanova D. Sambucus ebulus - from traditional medicine to recent studies. Scr Sci Med. 2013; 45 (2): 36-43.

146. Thompkinson DK, Bhavana V, Kanika P. Dietary approaches for management of cardiovascular health- a review. J Food Sci Technol. 2014;51(10):2318-30.

147. Tighe P, Duthie G, Vaughan N, Brittenden J, Simpson WG, Duthie S et al. Effect of increased consumption of whole-grain foods on blood pressure and other cardiovascular risk markers in healthy middle-aged persons: a randomized controlled trial. Am J Clin Nutr 2010; 92(4):733-40.

148. Todorov E. Ancient Thracian heritage in Bulgarian folklore. Nauka i izkustvo; 1972. Bulgarian.

149. Tokarz P, Kaarniranta K, Blasiak J. Role of antioxidant enzymes and small molecular weight antioxidants in the pathogenesis of age-related macular degeneration (AMD). Biogerontology. 2013; 14(5): 461-482.

150. Tovar J, Nilsson A, Johansson M, Björck I. Combining functional features of whole-grain barley and legumes for dietary reduction of cardiometabolic risk: a randomised cross-over intervention in mature women. Br J Nutr. 2014;111(4):706-14.

151. Toyoda Y, Thomson LR, Effect of dietary zeaxanthin on tissue distribution of zeaxanthin and lutein in quail. Invest Ophthalmol Vis Sci. 2002;43(4):1210-21.

152. Vallverdú-Queralt A, Regueiro J, de Alvarenga JF, Torrado X, Lamuela-Raventos RM. Carotenoid profile of tomato sauces: effect of cooking time and content of extra virgin olive oil. Int J Mol Sci. 2015; 16(5):9588-99.

153. Viguiliouk E, Kendall CW, Blanco Mejia S, Cozma AI, Ha V, Mirrahimi A, et al. Effect of tree nuts on glycemic control in diabetes: a systematic review and meta-analysis of randomized controlled dietary trials. PLoS One. 2014; 9(7).

154. Whitehead A, Beck EJ, Tosh S, Wolever TM. Cholesterol-lowering effects of oat $\beta$-glucan: a metaanalysis of randomized controlled trials. Am J Clin Nutr. 2014;100(6):1413-21.

155. Wijnhoven T, van Raaij J, Breda J. WHO European childhood obesity surveillance initiative. Implementation of round $1(2007 / 2008)$ and round 2 (2009/2010). WHO Report, 2014.

156. Wildman REC (editor). Handbook of nutrceuticals and functional foods. CRC Press 2001.

157. Wolfram T, Ismail-Beigi F. Efficacy of high-fiber diets in the management of type 2 diabetes mellitus. Endocr Pract 2011; 17(1):132-42.

158. Wu MH, Tsai YT, Hua KT, Chang KC, Kuo ML, Lin MT. Eicosapentaenoic acid and docosahexaenoic acid inhibit macrophage-induced gastric cancer cell migration by attenuating the expression of matrix metalloproteinase 10. J Nutr Biochem. 2012;23(11):1434-9.

159. Xavier Medina F. Mediterranean diet, culture and heritage: challenges for a new conception. Public Health Nutr. 2009;12(9A):1618-20.

160. Yasuda $M$, Yasutake $K$, Hino M, Ohwatari $H$, Ohmagari N, Takedomi K, Tanaka T, Nonaka G. Inhibitory effects of polyphenols from water chestnut (Trapa japonica) husk on glycolytic enzymes and postprandial blood glucose elevation in mice. Food Chem. 2014; 165:42-9.

161. Ye EQ, Chacko SA, Chou EL, Kugizaki M, Liu S. Greater whole-grain intake is associated with lower risk of type 2 diabetes, cardiovascular disease, and weight gain. J Nutr. 2012 Jul;142(7):1304-13.

162. Zanatta L, Rosso A, Folador P, Figueiredo MS, Pizzolatti MG, Leite LD, Silva FR. Insulinomimetic effect of kaempferol 3-neohesperidoside on the rat soleus muscle. J Nat Prod. 2008;71(4):532-5.

163. Zhang X., Shu XO, Gao YT et al., Soy food consumption is associated with lower risk of coronary heart disease in Chinese women. J Nutr. 2003; 133 (9): 2874-2878. 